\title{
Development and Analysis of a Lithium Carbon Monofluoride Battery-Lithium Ion Capacitor Hybrid System forHigh Pulse-Power Applications
}

\author{
Patricia H. Smith ${ }^{\mathrm{a}^{*}}$, Raymond B. Sepe, Jr. ${ }^{\mathrm{b}}$, Kyle G. Waterman ${ }^{\mathrm{b}}$, and L. Jeff Myron ${ }^{\mathrm{c}}$ \\ ${ }^{a}$ Naval Surface Warfare Center, Carderock Division \\ 9500 MacArthur Blvd. \\ West Bethesda, MD 20817-5000 \\ ${ }^{\mathrm{b}}$ Electro Standards Laboratories \\ 36 Western Industrial Dr. \\ Cranston, RI 02921-3403 \\ ${ }^{\mathrm{c} J S R}$ Micro \\ 1280 North Mathilda Ave. \\ Sunnyvale, CA 94089-1213 \\ *corresponding author: tel: (301) 227-4168; fax: (301) 227- 4732 \\ E-mail: patricia.h.smith1@navy.mil
}

Keywords: hybrid, lithium ion capacitor, $\mathrm{Li} / \mathrm{CF}_{\mathrm{x}} \mathrm{MnO}_{2}$ battery

\begin{abstract}
Although $\mathrm{Li} / \mathrm{CF}_{\mathrm{x}}$ and $\mathrm{Li} / \mathrm{CF}_{\mathrm{x}} \mathrm{MnO}_{2}$ have two of the highest energy densitiesof all commercial lithium primary batteries known to date, they are typically current-limited and therefore are not used in highpower applications. In this work, a $\mathrm{Li} / \mathrm{CF}_{\mathrm{x}} \mathrm{MnO}_{2}$ battery (BA-5790)was hybridized with a 1,000 F lithium ion capacitor to allow its use for portable electronic devices requiring $100 \mathrm{~W}$ one-minute pulses. An intelligent, power-management board was developed for managing the energy flow between the components. The hybrid architecture was shown to maintain the battery current to a level that minimized energy loss and thermal stress. The performance of the $\mathrm{Li} / \mathrm{CF}_{\mathrm{x}} \mathrm{MnO}_{2}$ hybrid was compared to the standard $\mathrm{Li} / \mathrm{SO}_{2}$ battery (BA-5590). The hybrid was shown to deliver the same number of $100 \mathrm{~W}$ pulse cycles as two BA-5590 batteries, resulting in a weight savings of $30 \%$ and a volumetric reduction of $20 \%$. For devices requiring 8 hours of operational time or less, a 5-cell $\mathrm{Li} / \mathrm{CF}_{\mathrm{x}} \mathrm{MnO}_{2}$ hybrid was found to be a lighter (55\%) and smaller (45\%) power source than the existing two BA-5590 battery option, and a lighter (42\%) and smaller(27\%) option than 1 1/2BA-5790batteriesalone. At higher power requirements (>100 W), further weight and size improvements can be expected.
\end{abstract}




\section{Introduction}

Portable electronic devices often have load profiles that consist of intermittent pulses of high power separated by a much longer, more modest baseline-power demand. One of the mainstay batteries used by the military for such applications has been the lithium/sulfur dioxide $\left(\mathrm{Li} / \mathrm{SO}_{2}\right)$-based BA-5590 primary battery. With an energy density of $\sim 200 \mathrm{Whkg}^{-1}\left(230 \mathrm{WhL}^{-1}\right)[1,2]$, the BA-5590 is noted for its ability to meet high-power requirements and to operate at low temperatures $\left(-40^{\circ} \mathrm{C}\right)$. However, major limitations of the BA-5590 for defense applications continue to be its weight and volume. The total weight of batteries required to complete a mission can be a logistics problem, thus reducing the fighting capability of the soldier. Additionally the military, similar to the consumer, desires miniaturized, less cumbersome devices. Reducing the weight and volume of the power source promotes user agility andwould be of great value to the Marine Corps and the Army.

Alternative technologies with higher energy densities have been developed, such as lithium/carbon monofluoride $\left(\mathrm{Li} / \mathrm{CF}_{\mathrm{x}}\right)$ which have approximately twice the energy density of $\mathrm{Li} / \mathrm{SO}_{2}$ cells (Table I). However to date, $\mathrm{Li} / \mathrm{CF}_{\mathrm{x}}$ technologies have not replaced the $\mathrm{Li} / \mathrm{SO}_{2}$ in military dominance due to their inability to meet the power demands required for numerous electronic devices. The limited high-rate performance of the $\mathrm{Li} / \mathrm{CF}_{\mathrm{x}}$ battery is thought to be the result of kinetic limitations associated with breaking $\mathrm{C}-\mathrm{F}$ bondsand the poor electrical conductivity of the $\mathrm{CF}_{\mathrm{x}}$ materialcreating high internal impedance during discharge $[3,4]$.

Over the years,numerous attempts to increase the ratecapability of the $\mathrm{Li} / \mathrm{CF}_{\mathrm{x}}$ electrochemistryand thereby increase operational life have had limited success. $\mathrm{CF}_{\mathrm{x}}$ is an intercalation compound formed by the reaction between carbonpowder and fluorine gas. This process forms strong covalent $\mathrm{C}-\mathrm{F}$ bonds with $\mathrm{sp}^{3}$ hybridization that induces charge localization and results in a significant reduction in electrical conductivity as the value of $\mathrm{x}$ increases[5].Approaches to solving the issue of low electrical conductivityto improve rate capability while maintaining a high energy densityinclude: partial carbon 
fluorination so that any unreacted carbon can serve as a conductor between the $\mathrm{CF}_{\mathrm{x}}$ particles[6,7],carbothermal treatment of the $\mathrm{CF}_{\mathrm{x}}$ that results in the formation of sub-fluorinated $\mathrm{CF}_{\mathrm{x}}[8]$, and pretreatment of $\mathrm{CF}_{\mathrm{x}}$ using a "solvated electron" reduction method to obtain a thin layer of graphitic carbon coating on the $\mathrm{CF}_{\mathrm{x}}$ particle surfaces[9]. Additionalmaterial approaches to improving poor-rate performance have included blendingCF $\mathrm{x}_{\mathrm{x}}$ with more conductive cathode materialssuch as manganese dioxide $\left(\mathrm{MnO}_{2}\right)$, with the expectation that an optimizedcathode mixtureratio would provide enhancedcell rate capability while maintaining the high energy density advantage of $\mathrm{CF}_{\mathrm{x}}[10]$. Thesestudiesdemonstrated promising improvements in cathode rate capability, though none were at a level required for future high-power portable devices. Thus batteries composed of $\mathrm{CF}_{\mathrm{x}}$ cathode materialsstill cannot deliver their full capacity under high-power conditions, making them an unsuitable replacement for the low energy density $\mathrm{Li} / \mathrm{SO}_{2}$-based batteries in military applications.

A hybrid battery-capacitor architecturecontaining both a high-energy device (battery) and a high-power device (capacitor) is a potential solution to address the unmet military need for light, miniaturized devices that can providea series of intermittent high-power pulses superimposed over a steady, low-power baseline.Combining a battery with a capacitor allows the capacitor to support the high-power transients, thus lowering the battery discharge current and improving energy utilization. In a $\mathrm{CF}_{\mathrm{x}}$ battery-capacitor hybrid, each component wouldoperate under optimal discharge rate conditions: short-duration, highpower pulses are supplied by the capacitor, and the $\mathrm{CF}_{\mathrm{x}}$ battery operating at low to moderate discharge rates fulfills the baseline power demand. During periods of low-power events, the $\mathrm{CF}_{\mathrm{x}}$ battery would recharge the capacitor.

Several studies have indicated success in utilizing hybrids with capacitors to improve the usable capacity of primary lithium and non-lithium batteries in applications requiring high-power pulses. However, few have focused on providing such augmentation while minimizing weight and volume - key for military applications. Most previous investigations have used electrochemical double layer capacitors (EDLCs) for 
the high-power component. Atwater et al. observed a significant improvement in a primary zinc-air battery using a simplistic hybrid design consisting of the battery and an EDLC in parallel with no interface electronics [11]. The hybrid zinc-air achieved double the number of high-power pulses compared to the battery alone. Penella et al. [12] observed a 33\% improvement in runtime with a primary, silver oxide-zinc battery when hybridized with an EDLC and more recently, Cain et al. [13] noted a 46\% increase in retrievable energy from a primary $\mathrm{Li} / \mathrm{MnO}_{2}$ battery. A larger number of studies have also focused on hybridizing secondary (rechargeable) batteries with EDLCs. For example, Cain et al. observed a $40 \%$ increase in capacity with a lithium ion rechargeable battery in the above study [13]. Others have also investigated hybridization of lithium ion batteries with EDLCs as a method to increase cycle life and improve operating temperature performance, in addition to extending battery run time [14-19]. These enhanced properties are particularly relevant for electric, hybrid electric and plug-in vehicles where highpower surges can lead to excessive cell heating, battery degradation and safety concerns. To determine the viability of a hybrid system for these and other applications, significant experimental work, mathematical simulations, and investigations to improve power/energy management have been conducted [e.g., 20-21]. Though these studies have successfully demonstrated improved battery performance, a thorough analysis of the weight and size of the devices has often been neglected.

The benefits of a hybrid battery-EDLC power source, unfortunately, are not without consequences. Enhanced battery performance can be at the expense of the overall system's weight, volume and complexity [22-24]. Theserepercussionsareparticularly damaging for portable applicationswhen long (> 30 seconds) high-power pulses are required. EDLC's have low energy density compared to batteries. A capacitor bank would therefore need to be oversized to meet a long-duration pulse requirement, resulting in poor realization for portable military applications. However, recent developments in EDLCshave made the development of hybrid systems requiring long pulse times significantly more feasible. 
Traditional EDLCs have a symmetric design comprised of two identical carbon electrodes, with a total cell capacitance equal to one half of the electrode capacitance. Recent efforts to develop higher energy density capacitors have led to an asymmetric design, where one of the double-layer carbon electrodes is replaced with a battery material that undergoes facile, reversible, Faradaic redox reactions [25]. Here, the capacitance of the battery electrode is more than 10 times that of the capacitive electrode $(\mathrm{C} 1>>\mathrm{C} 2)$. As a result, the total capacitance of an asymmetric cell is doubled that of the symmetric design. In addition, asymmetric capacitors typically operate at voltages $50 \%$ higherthan that of the symmetric capacitors. Therefore, the theoretical energy $\left(E=1 / 2 \mathrm{CV}^{2}\right)$ of an asymmetric capacitor is approximately four times greater than the symmetric design. One promising asymmetric capacitor that has demonstrated high energy density utilizes a carbon negative electrode which reversibly intercalates lithium. Referred to as

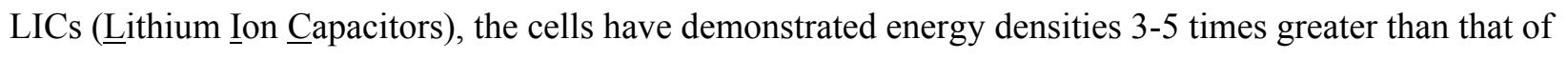
traditional EDLCs and exhibit a cycle life of 1,000,000. Unlike traditional EDLCs, LICs can hold charge for extensive periods of time ( $\sim 3-5 \%$ voltage loss after 3 months $)[26,27]$ allowing energy to be available for immediate use. They have also been found to be more abuse tolerant than lithium ion rechargeable batteries due to the lack of a Faradaic electrode [28].

To the best of our knowledge, there are no reports of hybridizing a primary lithium battery with a lithium ion capacitor. Furthermore, studies with EDLC-containing hybrids have rarely included an in-depth analysis on the size of such devices and their potential for portable applications. The present study reports our efforts to develop a novel hybrid power source that exploits the high energy density benefits of $\mathrm{CF}_{\mathrm{x}}$ batteries and the high power capability of a higher energy density capacitor. Our focus was to determine if, and under what conditions, a hybrid power source consisting of a $\mathrm{Li} / \mathrm{CF}_{\mathrm{x}} \mathrm{MnO}_{2}$ battery and a LIC would be more advantageous than the conventional, $\mathrm{Li} / \mathrm{SO}_{2} \mathrm{BA}-5590$ batteryfor portable devices requiringone-minute $100 \mathrm{~W}$ pulses. 


\section{Test Procedures and Hybrid Design}

\subsection{Materials}

$\mathrm{Li} / \mathrm{CF}_{\mathrm{x}} \mathrm{MnO}_{2}$ D-cells and batteries were manufactured at Eagle Picher Technologies (Joplin, MO). The cell, with a nominal capacity of $16 \mathrm{Ah}$, utilized an aluminum case and weighed $81 \mathrm{~g}$. The percentage of the active cathode materials was not known and is proprietary. The electrolyte consisted of a blend of dimethoxyethane, propylene carbonate, tetrahydrofuranand lithium perchlorate. The 10 -cell $\mathrm{Li} / \mathrm{CF}_{\mathrm{x}} \mathrm{MnO}_{2}$ battery, identified as the BA-5790 (Figure 1a), had a rated capacity of $15 \mathrm{Ah}$ when operated at the $24 \mathrm{~V}$ mode and $30 \mathrm{Ah}$ when operated at the $12 \mathrm{~V}$ mode. The BA-5790 (61.0 mm x $111.8 \mathrm{~mm} \times 127.0 \mathrm{~mm})$ weight was $1030 \mathrm{~g}$. The halfBA-5790 (Figure 1b), composed of five D-cells, weighed531g and had a rated capacity of $15 \mathrm{Ah}$ at $12 \mathrm{~V}$.

$\mathrm{Li} / \mathrm{SO}_{2}$ D-cells (LO $26 \mathrm{SHX}$ ) and ten-cell batteries (BA-5590 B/U, Figure 1c) were manufactured at SAFT America (Valdese, NC). Unlike $\mathrm{Li} / \mathrm{CF}_{\mathrm{x}} \mathrm{MnO}_{2}$ that contained a solid cathode material, $\mathrm{Li} / \mathrm{SO}_{2}$ cells consisted of a gaseous positive electrode material, $\mathrm{SO}_{2}$, dissolved in a solution of acetonitrile and lithium bromide. The nominal capacity of the $\mathrm{Li} / \mathrm{SO}_{2}$ cell was $7.5 \mathrm{Ah}$. The BA-5590 battery $(62.2 \mathrm{~mm} \times 111.8$ $\mathrm{mm} \times 127.0 \mathrm{~mm}$ ) had a rated capacity of $15 \mathrm{Ah}$ when operated at the $12 \mathrm{~V}$ mode and $7.5 \mathrm{Ah}$ whenoperated at the $24 \mathrm{~V}$ mode. The weights of the cell and BA-5590 B/U battery were $85 \mathrm{~g}$ and 1,006 g, respectively.

JM Energy (Yamanashi, Japan) supplied the prototype 1,000 F LIC (Figure 1d). The LIC was selected based on its availability, previous performance/safety analysis [28] and robust cell design. The design did not necessarily reflect improvements which may be incorporated in future, manufactured cells. The cells $(11 \mathrm{~cm} \times 7 \mathrm{~cm} \times 1.1 \mathrm{~cm})$ weighed $163 \mathrm{~g}$. The electrolyte consisted of a blend of ethyl methyl carbonate, ethylene carbonate, dimethyl carbonate and lithium hexafluorophosphate. An undisclosed ingredient was added as a flame retardant. 


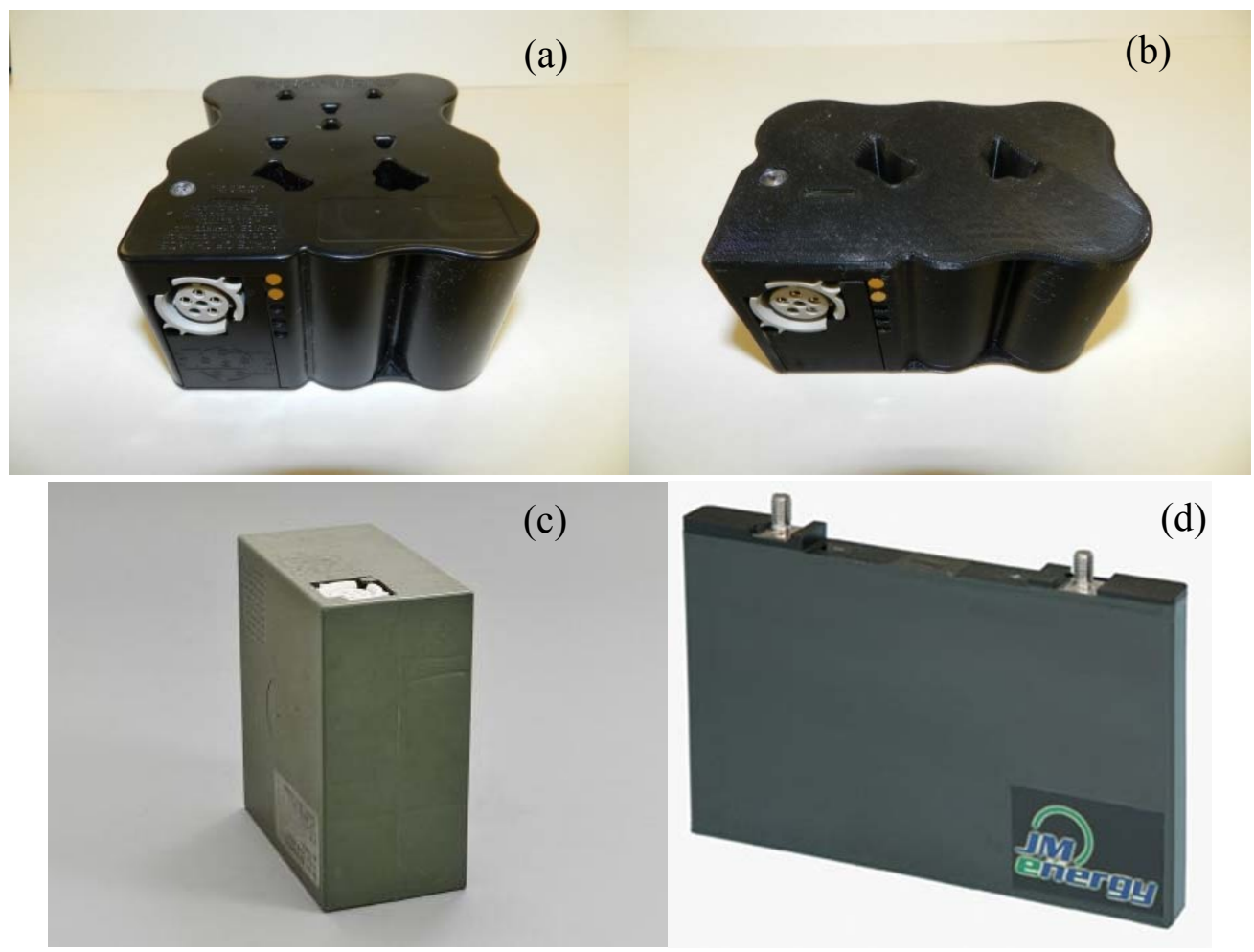

Fig. 1- Photograph of military batteries used in this investigation: (a) Eagle Picher $\mathrm{Li} / \mathrm{CF}_{\mathrm{x}} \mathrm{MnO}_{2} \mathrm{BA}-5790$ battery containing ten $\mathrm{Li} / \mathrm{CF}_{\mathrm{x}} \mathrm{MnO}_{2} \mathrm{D}$-cells, (b) Eagle Picher half BA-5790 battery containing five $\mathrm{Li} / \mathrm{CF}_{\mathrm{x}} \mathrm{MnO}_{2}$ D-cells, (c) Saft BA-5590 battery consisting of ten $\mathrm{Li} / \mathrm{SO}_{2}$ D-cells, and (d) 1,000 F LIC. 


\subsection{Hybrid Design}

The hybrid system consisted of three main parts: the battery, the capacitor, and the power management board. The power management board controlled the flow of energy between the battery and the capacitor in response to the load demand. It contained all the necessary sensors, microprocessor based controls, and switching power electronics to allow interconnection of the battery and the capacitor to realize hybrid operation. The board was sized $(12 \mathrm{~cm} \times 10.5 \mathrm{~cm} \times 0.16 \mathrm{~cm}, 71.5 \mathrm{~g})$ to fit within the footprint of a BA5590 package, making it suitable for portable military applications.

Thepower management board differed from a typical battery management system which is often responsible for balancing charge on a series string of rechargeable batteries. For this application the focus was on primary batteries and a single capacitor which do not require cell balancing. As our work progresses and rechargeable and series cells are employed within the hybrid, the power management function will expand to include battery management and cell balancing as well.A block diagram of the power management board is provided in Figure 2a. The power management algorithm which transitions the device between capacitor charge and discharge modes is diagramed in Figure $2 b$, and the electrical model of the hybrid system is depicted in Figure 2c.

The architecture of the hybrid system can be seen by examining Figure 2a.The battery is connected to the power management board, which routes the high power bus in parallel with a bidirectional DC/DC converter. Although prior investigations have used a direct connection between a battery and a bank of series connected EDLCs, that architecture limits the voltage range of the capacitors to that of the battery and therefore restricts the amount of energy that can be extracted from the capacitors. Other designs effectively connect a series bank of capacitors directly to the load in order to eliminate having a DC/DC converter (with its efficiency loss) directly in series with the capacitors [20]. However, that approach requires voltage cell balancing circuitry to ensure that charge is evenly distributed in the capacitors over a 

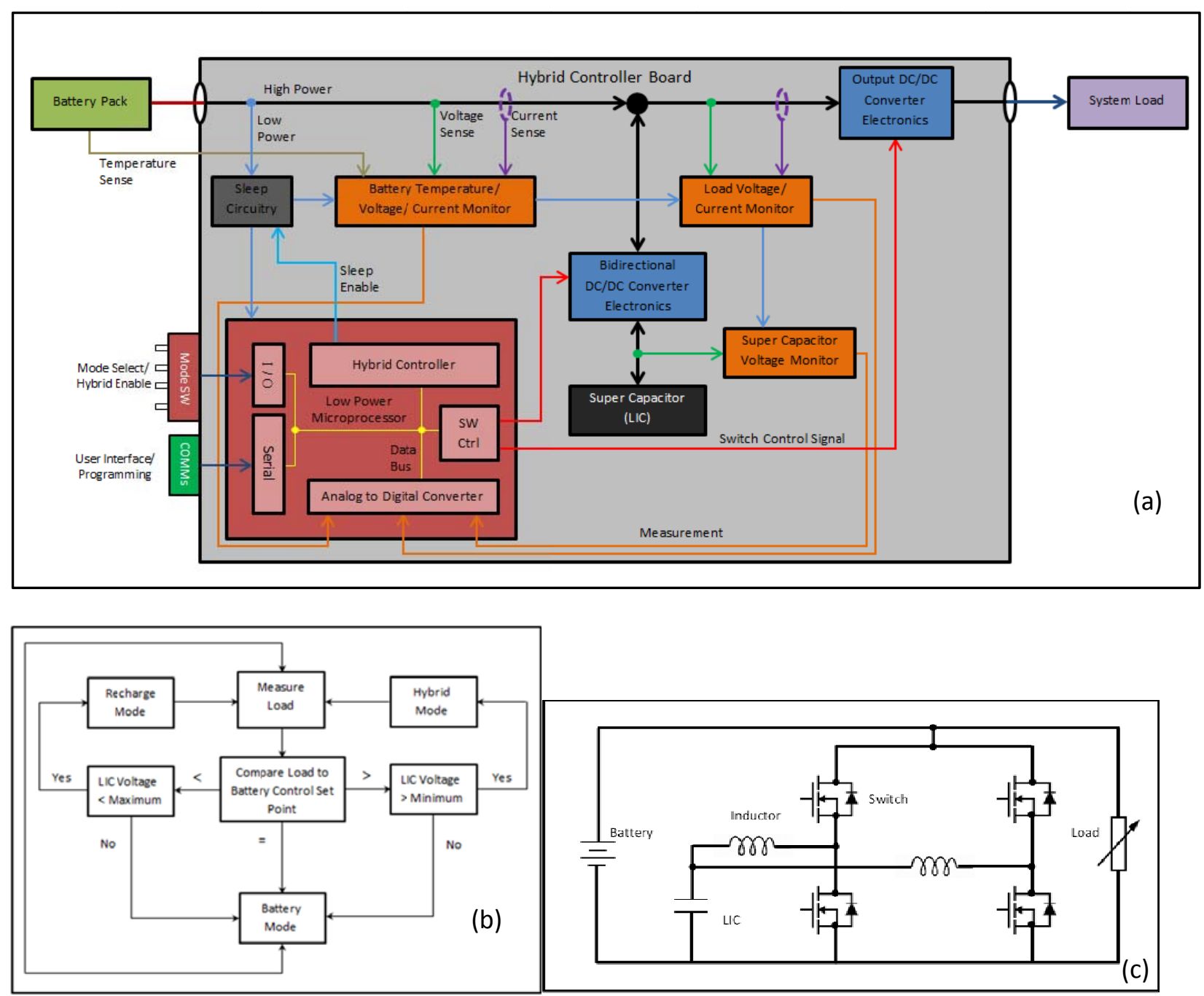

Fig.2-Hybrid system. (a) Block diagram of Intelligent Power Management Board. Main components include: a bi-directional DC/DC converter, a controller to manage the power distribution, a microprocessor, a serial link enabling direct communication with the power management board, a temperature sensor, and an output DC/DC converter, (b) power management algorithm flow, and (c). electrical model of the hybrid system. 
number of charge/discharge cycles. A direct connection to the load also means that the energy available from the capacitors is constrained by the allowable voltage variation of the load. In this study, a single LIC cell was used, thereby minimizing the size, cost, and complexity of the hybrid design. The bidirectional DC/DC converter in series with the LIC extracts the maximum energy from the LIC regardless of the battery or load voltage. The parallel connection of the battery pack and capacitor (via bidirectional DC/DC converter)was passed through an output DC/DC converter that allowed the user to generate a regulated voltage output to the load.For this study, the output DC/DC converter was not used.

The power management board (Figure 2a) consisted of several design elements including communications hardware and software, sleep circuitry, microprocessor/controller, and power electronics. A detailed description of each is provided below:

The communications hardware included serial receive/transmit circuitry necessary for enabling the user to directly communicate with the power management board.

The communications software allowed the user to vary the control configuration in order to conform to a particular experiment being conducted. For example, the battery current limits could bemodified through serial communications based upon the particular load power to be supported. The board also allowed the user to access instantaneous readings of the system measurements.

The sleep circuitryreducedthe system power consumption and thus improved overall system efficiency. It monitored the system to determine if any discernable load was present. If no load was detected, then a count-down was initiated before the system was put into a low-power mode. The low-power mode shut down all circuitry that was not required to maintain the system in a sleep state or to detect the presence of a load in the future. 
The microprocessor/controller executed the power management algorithm (Figure 2b), which allowed the device to operate in one of three distinct modes in response to an applied load. Monitored parameters used as inputs into this algorithm included battery current and voltage, load power and capacitor voltage. The three modes included: Hybrid, Recharge, and Battery. The Hybrid Mode was selected when the load requirements exceeded the defined battery control current set point and the LIC was not fully depleted. In this situation, the system functioned as a Hybrid by providing power to the load using contributions from both the LIC and battery (or the LIC only if the battery were depleted). The controller operated a bidirectional power converter to step up (boost) the voltage of the LIC from its nominal $3.0 \mathrm{~V}$ to the nominal $12.0 \mathrm{~V}$ of the main bus to assist in high load-power circumstances (Figure 2c). The Recharge Mode was selected when the load requirements were less than the defined control set point of the battery and the LIC voltage was measured to be less than the maximum defined. In this state, the controller operated the bidirectional power converter to step down (buck) the voltage from the battery to the LIC delivering power for the recharge. The Battery Mode was selected when the required load power was less than the defined battery control set point or when the load was greater than the battery set point but the LIC was depleted. The battery providedsole support of the load with all converter electronics disabled.

The power electronics circuitry incorporated a bidirectional DC/DC converter (Figure 2c)that enabled charging and discharging of the power dense LIC component in the hybrid architecture. The DC/DC converter bridged the voltage gap between the battery and LIC, allowing both to operate in the same system $\left(\mathrm{Li} / \mathrm{CF}_{\mathrm{x}} \mathrm{MnO}_{2}: \sim 14-10 \mathrm{~V}\right.$, LIC: $\left.\sim 3.8-2.2 \mathrm{~V}\right)$. The efficiency of the converter was typically $\sim 90 \%$ and was a function of the duty cycle resulting from the particular power level in which the hybrid system was operating. The current out of the battery was regulated to keep the battery operating efficiently via a proportional-integral current controller which varied the duty cycle on the MOSFET switches. In addition, the circuitry hadsafety 
features that monitored the LICto ensure operation within its recommended voltage range, ensured the maximum current rating of the MOSFETs was not exceeded, and monitored the battery voltage and temperature. The power electronics were shut down if any preset fault conditions were exceeded to protect the system.

Two unique hybrid designs were examined. The first was a "single-unit"(Figure 3a) with the same footprint as a BA-5X90 military battery $(6.2 \mathrm{~cm} \times 11.2 \mathrm{~cm} \times 12.7 \mathrm{~cm})$ and consisted of five $\mathrm{Li} / \mathrm{CF}_{\mathrm{x}} \mathrm{MnO}_{2}$ D-cells, a 1,000F LIC, and the power management board.The board was programmed so that the operating range of the LIC was $4.0 \mathrm{~V}-2.2 \mathrm{~V}$. The second design, referred to as the "Power Augmentor" $(12.5 \mathrm{~cm} \times 11.0 \mathrm{~cm} \times 3.8 \mathrm{~cm}, 380 \mathrm{~g}$, Figure $3 \mathrm{~b})$, was an attachable device containing only the power management board (Figure 3c) and capacitor. The Power Augmentorhad an ITT Cannon P/N CA 1108216 mating connector so that it could easily attach to a BA-5X90 battery (Figure 3c) when high power pulses were required, but removed for lower power demands. The Power Augmentor was programmed so that the LIC operated between $3.8 \mathrm{~V}$ and $2.2 \mathrm{~V}$. This voltage range was selected to ensure maximum rechargeablity $(1,000,000)$ by minimizing chemical reactions between the electrode and the electrolyte. Hybridization of both the BA-5X90 batteries wasevaluated with the Power Augmentor.

\subsection{Cell Characterization}

$\mathrm{Li} / \mathrm{CF}_{\mathrm{x}} \mathrm{MnO}_{2}$ and $\mathrm{Li} / \mathrm{SO}_{2} \mathrm{D}$-cells underwent galvanostatic testing at currents ranging from $1 \mathrm{~A}$ to $3 \mathrm{~A}$ to determine the effect of discharge rate on cell capacity and operating temperature. All tests wereconducted at ambient conditions. Two Type-K thermocouples(Omega Chromel/Alumel),held in place by electrical tape, were positioned on the outer circumference of the cell to monitor temperature every 3 minutes. Cells were placed in anexpanded 2 inch polystyrene insulating container with an $\mathrm{R}$ factor of approximately four. A MACCOR Series 4000 Automated Test System was used to discharge cells to an endpoint of 2.0 V. At least two cells were evaluated per test condition. Voltages were measured at least every 2 seconds. 
(a)
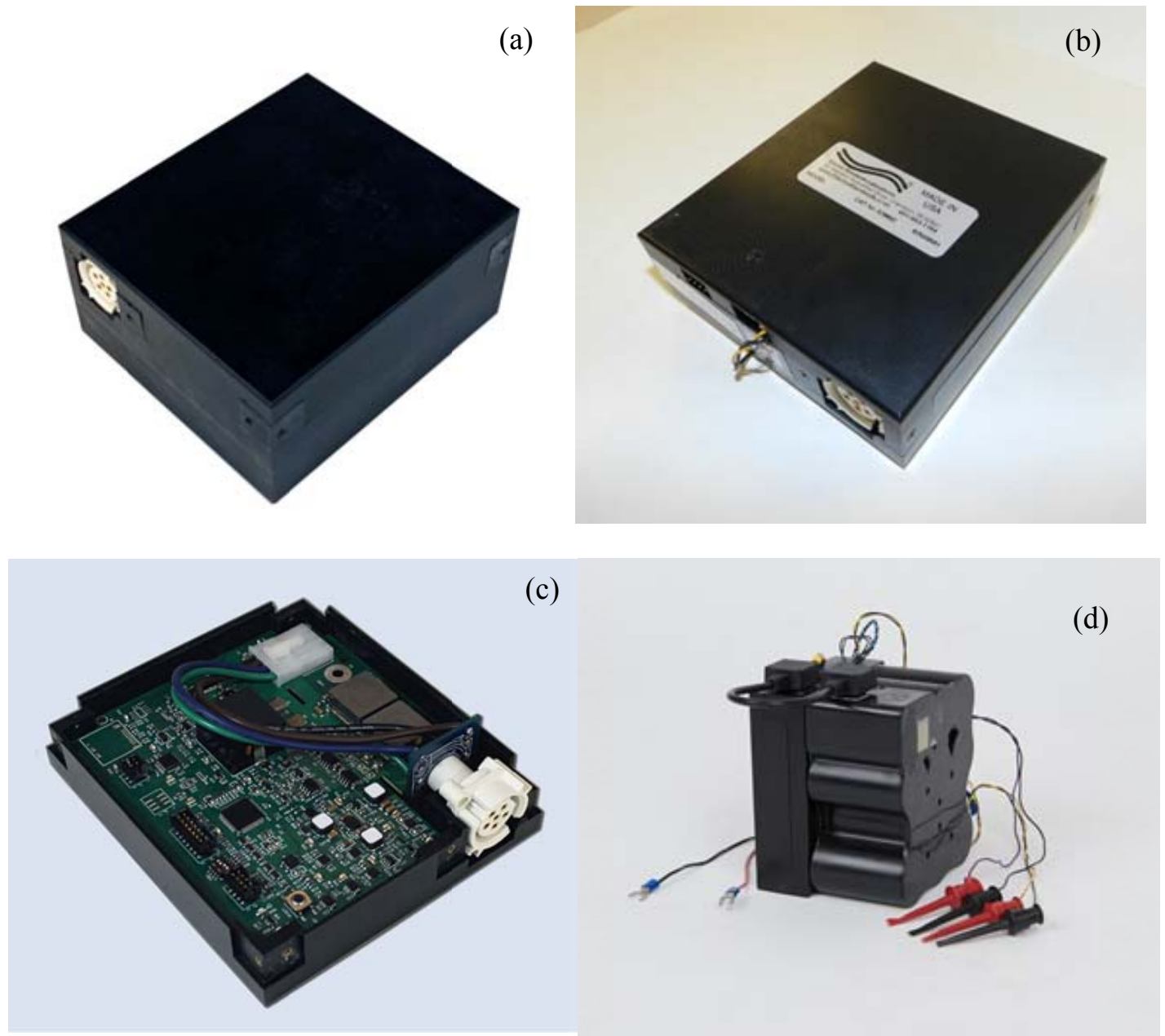

Fig. 3- Photograph of (a) the single unit hybrid having the same format of the BA-5X90 and consisting of five lithium D-cells, 1,000 F LIC, and power management board, (b) the attachable Power Augmentor consisting of the 1,000 F LIC and the power management board, (c) the power management board within the Power Augmentor, and (d).the Power Augmentor (with two pair of alligator clips used for voltage sensing in the laboratory test environment) attached to the BA-5790 battery. 
The $1,000 \mathrm{~F}$ LIC was cycled at a constant power of $100 \mathrm{~W}$ between $3.8 \mathrm{~V}$ and $2.2 \mathrm{~V}$ at ambient temperature using a MACCOR Series 4000 Automated Test System. Self-discharge was monitored by charging the cell and then measuring the voltage daily with a voltmeter.

\subsection{Battery and Hybrid System Evaluation}

Both the $\mathrm{Li} / \mathrm{CF}_{\mathrm{x}} \mathrm{MnO}_{2} \mathrm{BA}-5790$ and $\mathrm{Li} / \mathrm{SO}_{2} \mathrm{BA}-5590$ batteries and hybrid systems wereevaluated using either a MACCOR Series 4000 Automated Test System or a BK Precision 8500 DC Electronic Loader. The test procedure $[100 \mathrm{~W}$ for 1 minute, followed by $12 \mathrm{~W}$ for 9 minutes, repeat until the battery (or hybrid system) voltage fell to $10 \mathrm{~V}$ ] was designed to provide harsh conditions that would clearly demonstrate the effect of high-rate pulse load applications on battery/hybrid service life and temperature. Type-K thermocouples were taped onto the surface of batteries (ten positioned on the BA5790, six positioned on the BA5590) to monitor temperature during the test. (Note that although the hybrid's power management board had the capability for measuring battery temperature, external thermocouples were used for data collection in these experiments.) An Agilent 34970 Data Acquisition unit was used to monitor the cell/battery temperatures (at least every 3 minutes) and voltages (at least every 2 seconds). As a safety precaution, tests were conducted in a chemical fume hood with an averageair flowof 92 feet per minute.

\section{Results and Discussion}

\subsection{Cell Characterizations}

We evaluated $\mathrm{Li} / \mathrm{CF}_{\mathrm{x}} \mathrm{MnO}_{2}$ and LIC cells to determine the operational limits of the fundamental units of our hybrid design. Tests were conducted on $\mathrm{Li} / \mathrm{SO}_{2} \mathrm{D}$-cells for comparison purposes.

The voltage and temperature profiles of $\mathrm{Li} / \mathrm{CF}_{\mathrm{x}} \mathrm{MnO}_{2}$ D-cells discharged at various constant currents under ambient temperature conditions $\left(\sim 20^{\circ} \mathrm{C}\right)$ are shown in Figure $4 \mathrm{a}, \mathrm{c}$. Unlike $\mathrm{Li} / \mathrm{SO}_{2}$ cells that 

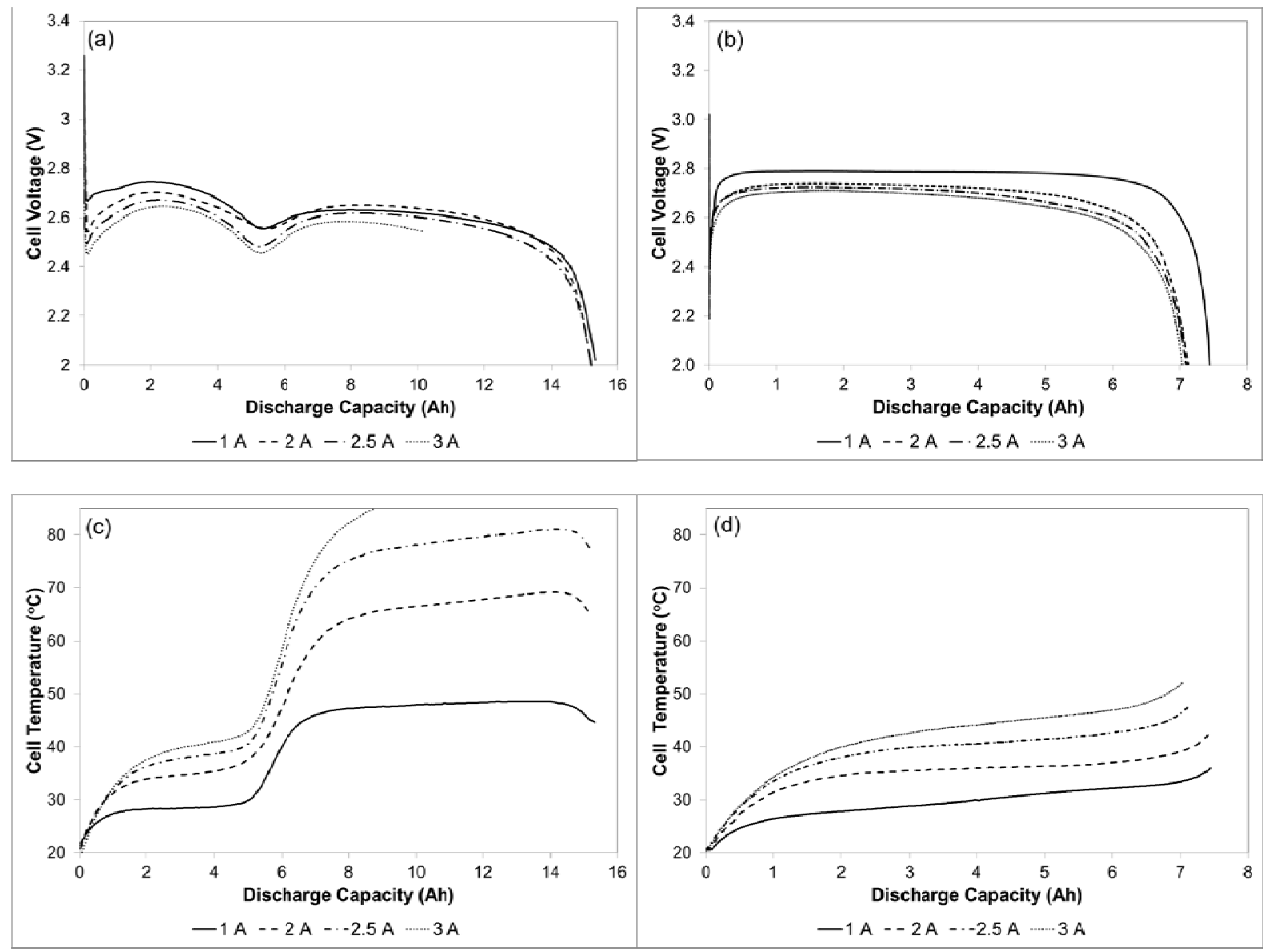

Fig. 4- Voltage and temperature profiles of $(a, c) \mathrm{Li} / \mathrm{CF}_{\mathrm{x}} \mathrm{MnO}_{2}$ and $(b, \mathrm{~d}) \mathrm{Li} / \mathrm{SO}_{2} \mathrm{D}$-cells discharged at a constant current of $1 \mathrm{~A}, 2 \mathrm{~A}, 2.5 \mathrm{~A}$ and $3 \mathrm{~A}$. 
displayed flat working voltages $(\sim 2.8$ to $2.7 \mathrm{~V}$, Figure $4 \mathrm{~b}), \mathrm{Li} / \mathrm{CF}_{\mathrm{x}} \mathrm{MnO}_{2}$ D-cells exhibited discharge profiles with two distinct plateaus attributed to the reduction of $\mathrm{MnO}_{2}(3.3 \mathrm{~V}$ to $\sim 2.5 \mathrm{~V})$ and $\mathrm{CF}_{\mathrm{x}}(\sim 2.5$ Vto $\sim 2.0 \mathrm{~V}$ ). Cell temperature increased sharply when the cell voltage entered the second plateau. At 3.0 A, only $\sim 60 \%$ of the rated capacity was delivered before the cell skin-temperature rose to $85{ }^{\circ} \mathrm{C}$ and the test was terminated for safety reasons. An increase in cell temperature with discharge rate has been previously reported for both $\mathrm{Li} / \mathrm{CF}_{\mathrm{x}}$ cells[29,30] and $\mathrm{Li} / \mathrm{CF}_{\mathrm{x}} \mathrm{MnO}_{2}$ batteries[31]. One possible explanation for the generated heat is the large activation energy associated with breaking C-F bonds. As noted by Read et al., a large activation energy would lead to poor kinetics during discharge and significant heat generation[32].Increased cell temperature has also been reported to result from the decomposition of an intermediate discharge product (i.e. $\mathrm{CFLi}_{\mathrm{x}}: \mathrm{S}_{\mathrm{y}}$ ), where $\mathrm{S}$ is a solvent molecule that is co-intercalated with the lithium upon discharge to form $\mathrm{LiF}$ and $\mathrm{C}[33,34]$. At currents $\leq 2.5 \mathrm{~A}$, high cell skin-temperatures did not limit performance and the high rated cell capacity(15 Ah) was achieved(Table II).

Thecorresponding voltage and skin-temperature profiles of $\mathrm{Li} / \mathrm{SO}_{2}$ D-cells discharged under identical conditions are show in Figure 4 b, d.At 3 A, the highest skin cell temperature observed was $\sim 50^{\circ} \mathrm{C}$ and cells delivered 7.0 Ah. There is therefore no benefit, in terms of delivered capacity, to use $\mathrm{Li} / \mathrm{CF}_{\mathrm{x}} \mathrm{MnO}_{2}$ in a hybrid system if cells are required to operate at $3 \mathrm{~A}$ or higher. At currents $\leq 2.5 \mathrm{~A}, \mathrm{Li} / \mathrm{CF}_{\mathrm{x}} \mathrm{MnO}_{2}$ cells provide twice the capacityasLi/ $\mathrm{SO}_{2}$ cells and there is a clear advantagefor their use.It should also be noted however that $\mathrm{Li} / \mathrm{SO}_{2}$ cells discharged at currents $\geq 2.0$ Aexhibiteda substantial voltage drop and subsequent voltage delay (Figure $4 b$ ) when the load was first applied. Voltage delay results from a passivation layer that forms on the surface of the lithium anode when exposed to electrolyte, solvent, or impurities [35]. Under normal operating conditions, the passivation layer does not affect cell performance. However, when a high-power load is placed on the cell, the resistance of the film can cause the cell's voltage to drop significantly. The cell voltage eventually recovers as the discharge progresses and the film is disrupted, but for certain applications, the voltage delay cannot be tolerated. 
The 1,000 F capacitor delivered 45 seconds at $100 \mathrm{~W}$ when it was discharged between $3.8 \mathrm{~V}$ and $2.2 \mathrm{~V}$, as shown in Figure 5. When the cell was charged to $3.8 \mathrm{~V}$, the self-discharge rate was $4 \%$ over 2 months. When charged to $3.0 \mathrm{~V}$, the self-discharge rate dropped to $\sim 0 \%$.

The cell investigations confirmed the following:

- A primary, lithium D-cell consisting of a $\mathrm{CF}_{\mathrm{x}}$ cathode material $\left(\mathrm{CF}_{\mathrm{x}} \mathrm{MnO}_{2}\right)$, delivered approximately twice the capacity as a cell utilizing a $\mathrm{SO}_{2}$ cathode when discharged at $\leq 2.5 \mathrm{~A}$. There is a significant energy density advantage (both gravimetric and volumetric) in using $\mathrm{Li} / \mathrm{CF}_{\mathrm{x}} \mathrm{MnO}_{2}$ cells as opposed to $\mathrm{Li} / \mathrm{SO}_{2}$ cells for portable electronic devices.

- The energy density advantage of a $\mathrm{Li} / \mathrm{CF}_{\mathrm{x}} \mathrm{MnO}_{2}$ cell may be over shadowed by safety concerns. Significant heat is generated when $\mathrm{CF}_{\mathrm{x}}$ is discharged at high rates. Cells discharge at $3 \mathrm{~A}$ can reach temperatures exceeding $85{ }^{\circ} \mathrm{C}$. Safety concerns may be exacerbated when cells are closely stacked together, as in a military BA-5X90 battery.

- The 1,000 F LIC cannot sustain a $100 \mathrm{~W}$ load for one minute. In a hybrid system, the battery would be required to power-share for applications requiring $100 \mathrm{~W}$ pulses for greater than 45 seconds.

- Unlike EDLCs, a LIC has a relatively low self-discharge rate. This should increase energy efficiency in prolonged hybrid use situations.

\subsection{Battery Characterizations}

In order to fully understand the benefit of a $\mathrm{Li} / \mathrm{CF}_{\mathrm{x}} \mathrm{MnO}_{2}-\mathrm{LIC}$ hybrid system, the $\mathrm{Li} / \mathrm{CF}_{\mathrm{x}} \mathrm{MnO}_{2} \mathrm{BA}-5790$ and $\mathrm{Li} / \mathrm{SO}_{2} \mathrm{BA}-5590$ batteries were assessed using the same test protocol as the hybrid. The $\mathrm{Li} / \mathrm{SO}_{2} \mathrm{BA}$ 5590 was evaluated as a benchmark, as it is commonly used in military applications.

The BA-5590 is constructed from two parallel strings of five $\mathrm{Li} / \mathrm{SO}_{2} \mathrm{D}$-cells connected in series $(5 \mathrm{~s} 2 \mathrm{p})$. Each nominally $12 \mathrm{~V}$ section has control electronics consisting of a current fuse, a thermal fuse and a 


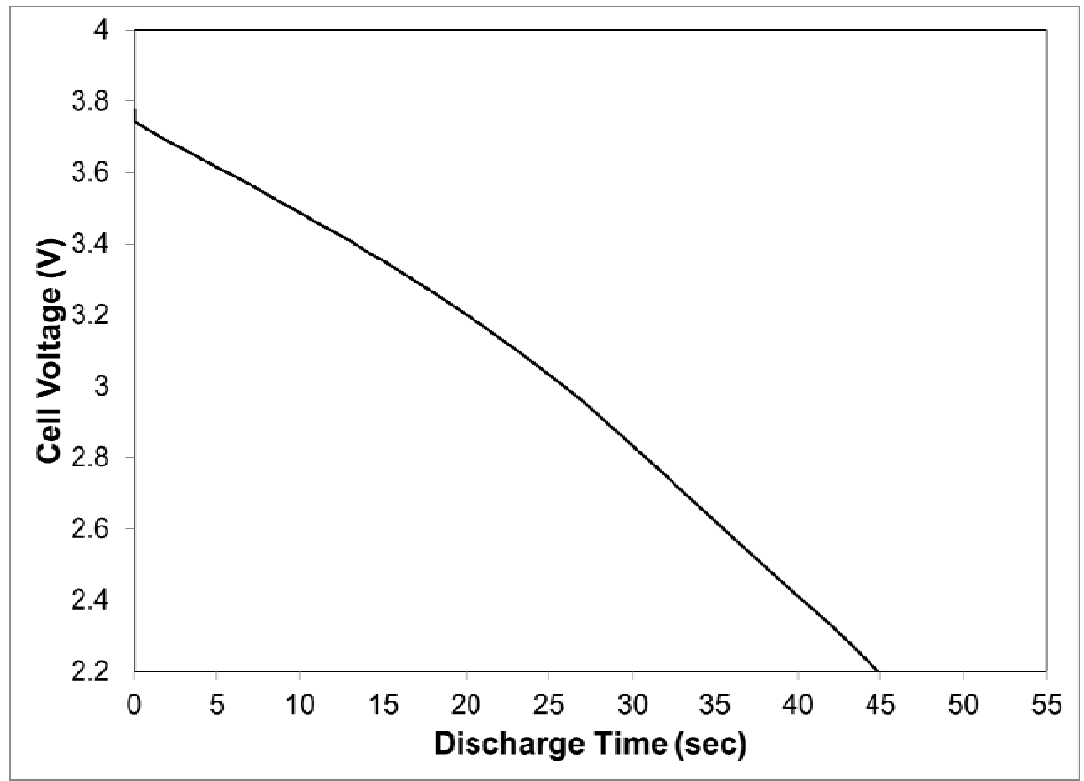

Fig. 5- Voltage profile of a 1,000 F LIC discharged at $100 \mathrm{~W}$. 
diode to prevent accidental charge. The plug connection from the battery allows the two strings to be discharged either in parallel $(12 \mathrm{~V})$ or in series $(24 \mathrm{~V})$, depending on the configuration of the mating electronics. When configured to deliver $12 \mathrm{~V}$, each string of cells has a limited current of $3 \mathrm{~A}$ as a safety precaution against overheating. As a result, the maximum power that can be drawn from a BA-5590 battery is approximately $72 \mathrm{~W}$.

Experimentsconfirmed that a singleLi/SO $\mathrm{SO}_{2} \mathrm{BA}-5590$ (5s2p)cannot deliver $100 \mathrm{~W}$ pulses (Table III). The 3 A fuse limit was immediately exceeded, and the voltage fell below the $10 \mathrm{~V}$ termination limit.Restarting the experiment proved ineffective. Only when two BA-5590s were connected in parallel(5s4p) was the test able to proceed and the battery deliver 100 complete cycles $(16.7 \mathrm{~h}$, Figure $6 \mathrm{a})$. It should be noted however, that two attemptswere required before the battery was able to discharge. During the first attempt, the initial $100 \mathrm{~W}$ pulse resulted in an immediate voltage drop below the cut-off voltage $(9.38 \mathrm{~V})$ and the test terminated. The second attemptwas able to proceed because the initial battery voltage was 0.6 $\mathrm{V}$ above the termination limit. The voltage dropsobservedin both tests areattributed mainly to a resistive lithium dithionite $\left(\mathrm{Li}_{2} \mathrm{~S}_{2} \mathrm{O}_{4}\right)$ anode filmresulting from the reaction of the soluble cathode, $\mathrm{SO}_{2}$, with lithium $[36,37]$.Once the experiment was underway, the $\mathrm{Li} / \mathrm{SO}_{2}$ battery displayed a flat cycling profile. An expansion of the discharge plot (Figure 6b) shows that during the 9-minute $12 \mathrm{~W}$ segments, the battery voltage was approximately $2 \mathrm{~V}$ higher than during the $100 \mathrm{~W}, 1$-minute pulse. The highest temperature observed on the outer surface of the BA-5590 case during the test was $35^{\circ} \mathrm{C}$.

The BA-5790, composed of ten, $\mathrm{Li} / \mathrm{CF}_{\mathrm{x}} \mathrm{MnO}_{2} \mathrm{D}$-cells (5s2p) and a 3 A fuse, was unable to sustain the 100 W load, similar to its $\mathrm{Li} / \mathrm{SO}_{2}$ counterpart (Table III). When the $100 \mathrm{~W}$ pulse commenced, the fuse limit was immediately reached and the voltage dropped below $10 \mathrm{~V}$. It was only when two $\mathrm{Li} / \mathrm{CF}_{\mathrm{x}} \mathrm{MnO}_{2} \mathrm{BA}-$ 5790 batteries were connected in parallel $(5 \mathrm{~s} 4 \mathrm{p})$ that the unit was able to support the $100 \mathrm{~W}$ load and deliver 208 cycles $(34.7$ h). The potential versus time graph (Figure 6c-d) showed the characteristic two- 

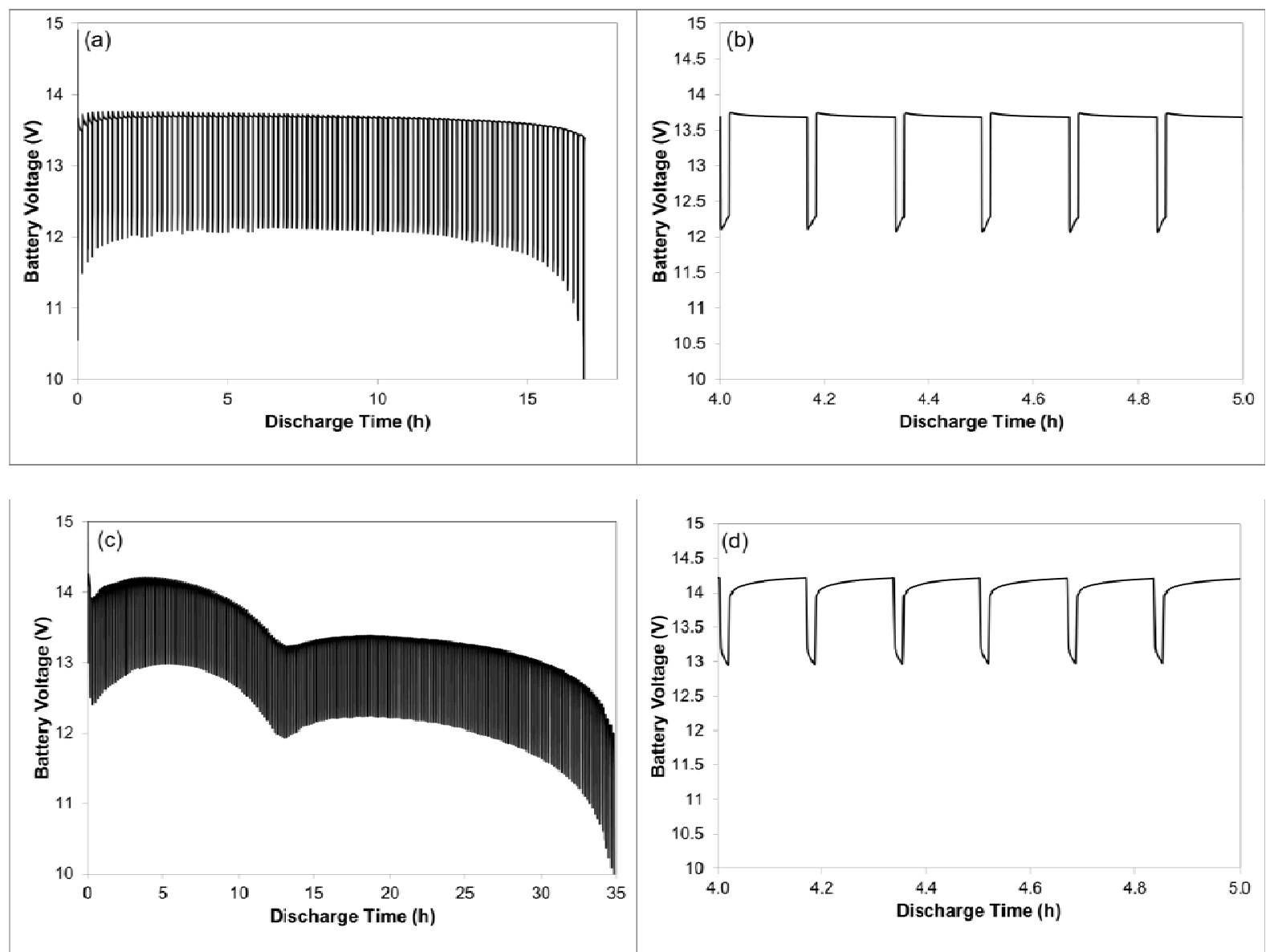

Fig. 6- Voltage profiles of two, BA-5X90 batteries connected in parallel (5s4p) and cycled according to the test protocol (1 minute at $100 \mathrm{~W}, 9$ minutes at $12 \mathrm{~W}$, repeat): $(\mathrm{a}, \mathrm{b}) \mathrm{Li} / \mathrm{SO}_{2} \mathrm{BA}-5590$ batteries [It should be noted that during the initial $100 \mathrm{~W}$ pulse, the battery voltage fell to $9.38 \mathrm{~V}$ (below the cut-off voltage). Only after restarting the experiment could the test continue], and (c, d) $\mathrm{Li} / \mathrm{CF}_{\mathrm{x}} \mathrm{MnO}_{2} \mathrm{BA}-5790$ batteries. Figures $b$ and $d$ are expanded versions of plots a and $c$, for clarity. 
voltage plateauobserved with the D-cells. The highest temperature recorded on the outer surface of the battery case was $\left(50^{\circ} \mathrm{C}\right)$.

The battery investigations confirmed the following:

- SingleLi/ $/ \mathrm{SO}_{2} \mathrm{BA}-5590$ and $\mathrm{Li} / \mathrm{CF}_{\mathrm{x}} \mathrm{MnO}_{2} \mathrm{BA}-5790$ batteries $(5 \mathrm{~s} 2 \mathrm{p})$ cannot deliver $100 \mathrm{~W}$ pulses. The $3 \mathrm{~A}$ fuse limit is exceeded. Thus battery-capacitor hybrids must maintain the battery current $<3 \mathrm{~A}$.

- Two Li/ $\mathrm{CF}_{\mathrm{x}} \mathrm{MnO}_{2} \mathrm{BA}-5790$ batteries in parallel $(5 \mathrm{~s} 4 \mathrm{p})$ can deliver twice the capacity as two $\mathrm{Li} / \mathrm{SO}_{2} \mathrm{BA}$ 5590s in parallel $(5 \mathrm{~s} 4 \mathrm{p})$.

- The temperature of the $\mathrm{Li} / \mathrm{SO}_{2} \mathrm{BA}-5590$ and $\mathrm{Li} / \mathrm{CF}_{\mathrm{x}} \mathrm{MnO}_{2} \mathrm{BA}-5790$ batteries increases during highpower discharge.

- The Li/SO $\mathrm{SO}_{2} \mathrm{BA}-5590$ can exhibit significant voltage drop during initialhigh-power discharge.

\subsection{Hybrid Investigations}

Given the power limitations of the high energy density $\mathrm{Li} / \mathrm{CF}_{\mathrm{x}} \mathrm{MnO}_{2} \mathrm{BA}-5790$, we developed a hybrid power system that would give the military the option of using $\mathrm{Li} / \mathrm{CF}_{\mathrm{x}} \mathrm{MnO}_{2}$ batteries for both low and high power applications. Our goal was a power source that was lighter and smaller than the present $\mathrm{Li} / \mathrm{SO}_{2} \mathrm{BA}-5590$. To accomplish this objective, an intelligent power management board was developed to manage the energy flow between the battery and the capacitor (Section 2.2).

Under optimal conditions, the LIC capacitance would be sized to meet the entire 1-minute, $100 \mathrm{~W}$ pulseload, eliminating battery stress during the pulse and prolonging battery life. During the course of this investigation however, limited cell sizes (capacities) were available due to the newly emerging LIC technology. Of those that were available, the 1,000 F (0.44 Ah) cell was selected for use based on its small profile. However, the 1,000 F capacitor couldonly operate for 45 seconds when discharged at 100 $\mathrm{W}$ between $3.8 \mathrm{~V}$ and $2.2 \mathrm{~V}$ (see Section 3.1) and thus, the full advantage of the hybrid could not be realized. Accordingly, the board was programmed to allow the battery to work in tandem with the 
capacitor to meet the high-power load. Given safety concerns regarding the temperature rise of $\mathrm{Li} / \mathrm{CF}_{\mathrm{x}} \mathrm{MnO}_{2}$ D-cells at high currents (Figure 4c), and the additional limitations of heat transfer when cells are assembled within the BA-5790 battery case, the power management board was configured to limit cells to the minimum current required to meet the load demands. For hybrid systems incorporating $5 \mathrm{~s} 2 \mathrm{p}$ and $5 \mathrm{~s} 4 \mathrm{p}$ batteries, the board was programmed so that the cell current never exceeded $2.5 \mathrm{~A}$ and $1.5 \mathrm{~A}$ during the $100 \mathrm{~W}$ and $12 \mathrm{~W}$ load pulses, respectively. For hybrid systems with $5 \mathrm{~s} 1 \mathrm{p}$ batteries, the limit was increased to $2.9 \mathrm{~A}(100 \mathrm{~W})$ and $2.5 \mathrm{~A}(12 \mathrm{~W})$.

Despite the 45second LIC limitation, thehybrid designs in this study demonstrated an improved ability to deliver high-power pulses with reduced operating temperatures compared to non-hybridized BA-5790 batteries. As shown in Figure 7a, the single-unit $\mathrm{Li} / \mathrm{CF}_{\mathrm{x}} \mathrm{MnO}_{2}$ hybrid design (Figure 3a) successfully deliveredfifty-100 W pulses, whereasa single, $\mathrm{Li} / \mathrm{SO}_{2} \mathrm{BA}-5590$ battery did not deliver any (Section 3.2). The voltage profiles of both the hybrid and the battery component displayed two distinct plateaus that were similarly observed for the $\mathrm{Li} / \mathrm{CF}_{\mathrm{x}} \mathrm{MnO}_{2}$ D-cell (Figure 4a). As expected, an expansion of the voltage profiles clearly demonstratedthat both the LIC and the battery contributed to the100 $\mathrm{W}$ load-demands, while the battery provided sole power during the $12 \mathrm{~W}$ loads (Figure $7 \mathrm{~b}$ ). The battery and hybrid voltage immediately fell at the initiation of the high-power pulse. Both voltages remained low as the two components supported the $100 \mathrm{~W}$ load. Upon completion of the 1-minute pulse, the hybrid voltage increased while the battery voltage continued to decline as it accommodated the $12 \mathrm{~W}$ load and charged the LIC. Once the capacitor was fully charged, the battery voltage rapidly increased and then remained relatively constant until the next high-power load pulse.

During this test, the battery temperature appeared to plateau around $62{ }^{\circ} \mathrm{C}$ (Figure 7a). In contrast, an unhybridized five-cell $\mathrm{Li} / \mathrm{CF}_{\mathrm{x}} \mathrm{MnO}_{2}$ battery ( $5 \mathrm{~s} 1 \mathrm{p}, 3 \mathrm{~A}$ fuse removed) that was subjected to identical testing demonstrated cell temperatures exceeding $70{ }^{\circ} \mathrm{C}$ (Figure 7c) and the experiment was terminated due to safety concerns. 

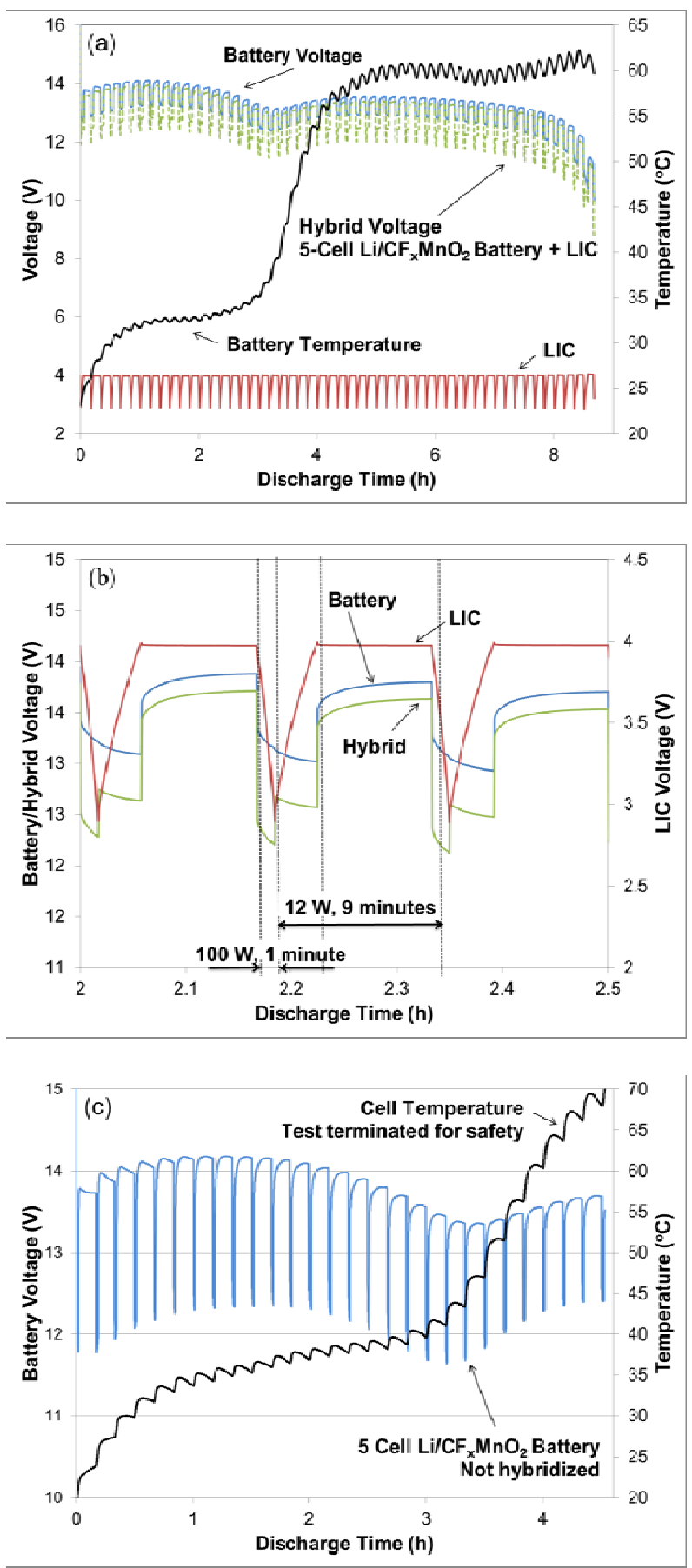

Fig. 7- Voltage profiles of (a-b) a five D-cell $\mathrm{Li} / \mathrm{CF}_{\mathrm{x}} \mathrm{MnO}_{2}$ battery - LIC hybrid, and (c) a five D-cell $\mathrm{Li} / \mathrm{CF}_{\mathrm{x}} \mathrm{MnO}_{2}$ non-hybridized battery without a $3 \mathrm{~A}$ fuse, cycled according to the test protocol (1 minute at $100 \mathrm{~W}, 9$ minutes at $12 \mathrm{~W}$, repeat). 
(Although the manufacture states thatcells can operation to $85^{\circ} \mathrm{C}$, an upper limit of $70^{\circ} \mathrm{C}$ was selected for experiment termination based on military specification MIL-STD-1472F.)In addition to safety concerns, high operating battery temperatures accelerate chemical reactions and accelerate aging. Therefore, hybrid architectures are not only a technique to reduce cell temperatures and improve battery safety,but can also extend battery life.

After the successful demonstration of the power management board in the single-unit configuration, the board was then coupled to the 1,000 F LIC and placed in a durable housingas a detachable, reusable unit (Power Augmentor) to provide boost power as needed. When the Power Augmentor was coupled to a half-sizeLi/ $\mathrm{CF}_{\mathrm{x}} \mathrm{MnO}_{2} \mathrm{BA}-5790$ (5s1p), the unit delivered 58 cycles(Table III), achieving similar results as the single-unit design described above. Connecting onefull-size $\mathrm{Li} / \mathrm{CF}_{\mathrm{x}} \mathrm{MnO}_{2} \mathrm{BA}-5790$ (5s2p) with the Power Augmentorresulted in96 cycles(Figure 8a) - approximately the same number of cycles achieved with two, $\mathrm{Li} / \mathrm{SO}_{2} \mathrm{BA}-5590$ batteries (5s $4 \mathrm{p}$, Figure $6 \mathrm{a}$ ). This equates to a $49 \%$ reduction in disposable battery weight (Table III) and a 30\% reduction in total weight (battery and Power Augmentor). A low disposal battery weight is desirable, as itis a reflection ofthe burden to supply batteries to the field.

During testing of the BA-5790 (5s2p)-Power Augmentor hybrid, the temperature of one $\mathrm{Li} / \mathrm{CF}_{\mathrm{x}} \mathrm{MnO}_{2}$ cell rose to $65{ }^{\circ} \mathrm{C}$ (Figure $8 \mathrm{~b}$ ). The hottest cells were located in the center of the battery. This is in agreement with thermal conductivity modeling and measurements previously studied by Listerund et al. [31]. In comparison, the highest battery temperature observed with two $\mathrm{Li} / \mathrm{SO}_{2}$ BA-5590s connected in parallel $(5 \mathrm{~s} 4 \mathrm{p})$ was $33{ }^{\circ} \mathrm{C}$. However the actual $\mathrm{Li} / \mathrm{SO}_{2}$ cell temperature may have been higher. Unlike the conformal $\mathrm{Li} / \mathrm{CF}_{\mathrm{x}} \mathrm{MnO}_{2} \mathrm{BA}-5790$ design (Figure 1a) that allowed thermocouple positioning directly over the individual cells, the $\mathrm{Li} / \mathrm{SO}_{2} \mathrm{BA}-5590$ design is cuboid (Figure 1c) and has stagnant air pockets aroundthe cells. For the Li/SO2 BA-5590, thermocouples were placed on the center of each face of the battery case and were not located directly over each cell. It should be noted that the 1 minute, $100 \mathrm{~W}$ pulse 

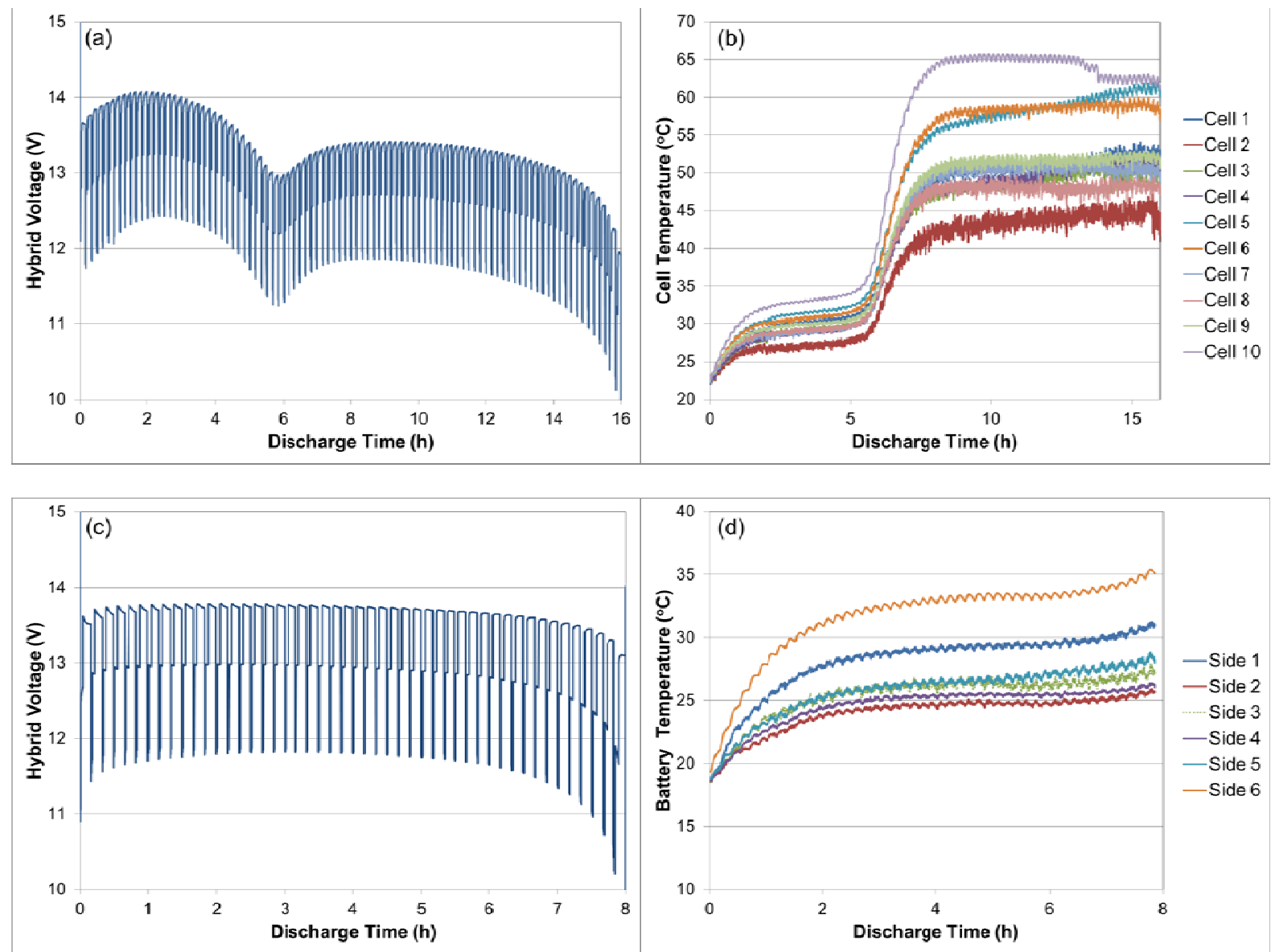

Fig. 8- Voltage and temperature profiles of one BA-5X90 battery (5s2p) - LIC hybrid system cycled according to the test protocol ( 1 minute at $100 \mathrm{~W}, 9$ minutes at $12 \mathrm{~W}$, repeat): (a, b) hybrid incorporating BA-5790 (10 Li/ $\mathrm{CF}_{\mathrm{x}} \mathrm{MnO}_{2}$ D-cells; thermocouples placed on case directly opposite individual cells), and (c, d) hybrid incorporating BA-5590 (10 Li/SO $\mathrm{SO}_{2} \mathrm{D}$-cells; thermocouples placed on the center of each face of the battery case). 
experiments conducted during this investigation represents extreme conditions and is not representative of field use. A considerable reduction in cell temperature can be achieved by reducing the pulse duration to 30 seconds. In the case of the hybridized $\mathrm{Li} / \mathrm{CF}_{\mathrm{x}} \mathrm{MnO}_{2}$ half-BA-5790 (5s1p), limiting the pulse duration to 30 seconds while maintaining the previous current settings on the power management board reduced the highest cell temperature by $15^{\circ} \mathrm{C}$.

The hybrid architecturewas shown to also benefitthe performance of the standard military $\mathrm{Li} / \mathrm{SO}_{2} \mathrm{BA}$ 5590 battery. Attachment of the Power Augmentor to a single BA-5590 allowed 47 cycles (Figure 8c) compared to 0 cycles with the non-hybridize battery (Section 3.2).Although the LIC was not observed to lowerthe battery operating temperature (Figure 8d), it did minimize voltage delay. The initial $100 \mathrm{~W}$ pulse remained above $10 \mathrm{~V}$ (Figure8c), compared to the non-hybridized system which resulted in a voltage drop to $9.38 \mathrm{~V}$ for two, BA-5590s $(5 \mathrm{~s} 4 \mathrm{p})$.

\subsection{Comparative Analysis}

To more clearly understand the potential benefit of a hybrid $\mathrm{Li} / \mathrm{CF}_{\mathrm{x}} \mathrm{MnO}_{2}$-LICdesign, a weight and volume analysis comparing hybrid systemsto the individual $\mathrm{Li} / \mathrm{SO}_{2}(\mathrm{BA}-5590)$ or $\mathrm{Li} / \mathrm{CF}_{\mathrm{x}} \mathrm{MnO}_{2}(\mathrm{BA}-5790)$ batterieswas conducted. Table IV summarizes the battery/hybrid weight and volume required for a 1minute $100 \mathrm{~W}$ pulse/9-minute 12 Wload profile over various mission durations ( $8 \mathrm{~h}, 16 \mathrm{~h}, 24 \mathrm{~h})$. Two BA-5590 Li/ $/ \mathrm{SO}_{2}$ batteries are presently needed to meet this requirement andthey have a weight and volume of $2060 \mathrm{~g}(2 \times 1030 \mathrm{~g})$ and $1766 \mathrm{~cm}^{3}\left(2 \times 883 \mathrm{~cm}^{3}\right)$ respectively. Thus, only those hybrid systems not exceeding $2060 \mathrm{~g}$ in weight or $1766 \mathrm{~cm}^{3}$ in volume were analyzed. Hybrid calculations were based on the Power Augmentor design unless otherwise noted.

The comparative analysis demonstrated that hybridization of a $\mathrm{Li} / \mathrm{CF}_{\mathrm{x}} \mathrm{MnO}_{2}$ BA-5790 battery $(5 \mathrm{~s} 1 \mathrm{p}$ configuration) with a 1,000 F LIC led to a significant savings in weight and volume for missions 8 hours or less. The PowerAugmentorwas found to reduce the weight and volume of the power source by 
$55 \%$ (wt.) and $45 \%$ (vol.) with respect toa BA-5590 ( $\left.\mathrm{Li} / \mathrm{SO}_{2}, 5 \mathrm{~s} 4 \mathrm{p}\right)$ battery and by $42 \%$ (wt.) and $27 \%$ (vol.)with respect toa $\mathrm{BA}-5790\left(\mathrm{Li} / \mathrm{CF}_{\mathrm{x}} \mathrm{MnO}_{2}, 5 \mathrm{~s} 3 \mathrm{p}\right)$ battery. It is important to note that these benefits were observed despite the LIC, power management board, and their assembly being far from optimized. Additional benefits in weight and volume would likely be realized with further refinement. Within the context of the current design, the advantage for durations between $8-16$ hours is less clear. The hybrid $(5 \mathrm{~s} 2 \mathrm{p})$ is superior ( $30 \%$ lighter, $20 \%$ smaller) to the existing BA-5590 ( $\left.\mathrm{Li} / \mathrm{SO}_{2}, 5 \mathrm{~s} 4 \mathrm{p}\right)$. However, althoughthe hybrid (5s2p) is 10\% lighter than the BA-5790 (5s3p) it is $6 \%$ larger. This trade-off between weight and volume may be advantageous with respect to the $\mathrm{Li} / \mathrm{CF}_{\mathrm{x}} \mathrm{MnO}_{2}$ electrochemistry as hybridization would reduce the battery operating current and thus lower the operating temperature.

It should be further noted that the results presented in this study suggest that the benefit of the hybrid becomes more pronounced as the power level is increased. This is a logical conclusion, as the LIC is a power-dense device implying significant benefit will be realized in the area of increased load-power requirements. For example, increasing the power level to $140 \mathrm{~W}$ from $100 \mathrm{~W}$ prohibits the use of the $1 \frac{1}{2}$ BA-5790 (5s3p) since the 3 A fuse limit per $5 \mathrm{~s} 1 \mathrm{p}$ battery string is exceeded and an additional $1 / 2$ BA-5790 $(5 \mathrm{~s} 1 \mathrm{p})$ is required.However, a hybrid configuration implementing the 1000F LIC with 1 BA-5790 (5s2p) is capable of supporting a 1-minute, profile with a high-power pulse of $140 \mathrm{~W}$. In regards to the comparative analysis during 1-minute $140 \mathrm{~W}$ challenges, the hybrid provides $\sim 30 \%$ improvement in weight and $\sim 20 \%$ improvement in volume. Substantially greater benefit can be realized using the hybrid technology as power levels are further increased. This is a noteworthyfinding as the results suggest that advanced portable electronics requiring greater power may be developed since they can now be supported by this technology without substantial penalty of weight.

\section{Conclusions}

To improve the high-power performance of lithium batteries containing $\mathrm{aCF}_{\mathrm{x}}$ cathode material, we investigated the use of a hybrid system utilizing a LIC. An intelligent power management board was 
developed to manage the energy flow between the battery and the capacitor. We showed that a detachable hybrid device,consisting of a 1,000 F LIC and a power management board, allows the military to utilizehigh energy density $\mathrm{Li} / \mathrm{CF}_{\mathrm{x}} \mathrm{MnO}_{2}(\mathrm{BA}-5790)$ batteriesfor applications requiring both low and high power. The capacitor was able to buffer the high-power demands of the load, thus reducing the stress on the battery, lowering cell operating temperature and achieving greater energy utilization. One $\mathrm{Li} / \mathrm{CF}_{\mathrm{x}} \mathrm{MnO}_{2} \mathrm{BA}-5790$ battery hybridized with a LIC deliveredapproximately the same capacity as two, $\mathrm{Li} / \mathrm{SO}_{2}$ BA-5590 batterieswhen cycled under a simulated communications testing protocol (100 W for 1 minute, 12

W for 9 minutes).A hybrid design could reduce the weight and volume of batteries required for high pulse-power devices. In theory, this wouldreduce the number of battery types used by the militaryand thus improve logistics and affordability. It should be noted that the benefits of a hybrid architecture observed in this study were achieved using an un-optimized LIC due to limited availability of a newly emerging technology. Increasing the capacitance/energy density of the LIC, or accepting a 45-second pulse instead of a 60 -second pulse, would allow the full benefit of the hybrid to be realized. Future efforts will focus on using higher energy density LICsas they become available.This would allow the LIC to meetthe entire $100 \mathrm{~W}$ one-minute pulse requirement, thus lowering the $\mathrm{Li} / \mathrm{CF}_{\mathrm{x}} \mathrm{MnO}_{2}$ cell current $(2.5 \mathrm{~A} \rightarrow 1.2 \mathrm{~A})$ and reducing BA-5790 battery operating temperatures.

\section{Acknowledgements}

This work was financially supported by the Office of Naval Research (Expeditionary Maneuver Warfare and Combating Terrorism Department) and is gratefully acknowledged.The authors would also like to acknowledge the contribution of Warren Baker (NSWC-Carderock) in assisting with experiments and to thank Felix Nunez (Eagle Picher Technologies) for valuable discussionsduring the course of this work.

\section{References}

[1] SAFT, Complete power solutions autonomy for fighters in the field, Doc. No. 32019-2-0909, http://dtsheet.com/doc/1376128/military-market-brochure/, 2009 (assessed 16.07/02). 
[2] M. Brundage, Future trends and thrusts for army manportable power sources, 2007 Joint Service Power Expo, San Diego, CA, 24-26 April 2007.

[3]R. Yazami, H. Touhara, Primary batteries - nonaqueous systems lithiumpolycarbonmonofluoride,Reference Module in Chemistry, Molecular Sciences and Chemical Engineering, (2014), 93-99.

[4] Y. Wang, B. Liu, Q. Li, S. Carmell, S. Ferrara, Z. D. Deng, J. Xiao,Lithium and lithium ion batteries for applications in microelectronic devices: A review, J. of Power Sources 286 (2015) 330-345.

[5]H. Groult,C.M. Julien, A. Bahloul, S. Leclerc, E. Briot, A. Porras-Gutierrez, and A. Mauger, in: T. Nakajima, H. Groult (Eds.), Advanced Fluorine-Based Materials for Energy Conversion, Elsevier, Waltham, MA, 2015 pp. 237-259.

[6] P. Lam, R. Yazami,Physical Characteristics and rate performance of $\left(\mathrm{CF}_{\mathrm{x}}\right)_{\mathrm{n}}(0.33<\mathrm{x}, 0.66)$ in lithium batteries, J. Power Sources 153 (2006) 354-359.

[7] R. Yazami, A. Hamwi, K. Guerin, Y. Ozawa, M. Dubois, J. Giraudet, F. Masin,Fluorinated carbon nanofibers for high energy and high power densities primary lithium batteries,Electrochem. Commun. 9 (2007) 1850-1855.

[8] S. Zhang, D. Foster, and J. Read,Carbothermal treatment for the improved discharge performance of

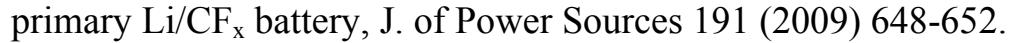

[9] D. Wipf, M. Mathews and C. Pittman Jr., Improved Li/CF $\mathrm{C}_{\mathrm{x}}$ cells with partial reduction of $\mathrm{CF}_{\mathrm{x}}$, IMLB, Como, Italy, June 10-14, 2014.

[10] X. Zhang, X. Wang, High capacity and high rate lithium cells with $\mathrm{CF}_{\mathrm{x}} \mathrm{MnO}_{2}$ hybrid, U.S. Patent 2009/0081545.

[11] T.B. Atwater, P.J. Cygan, and F.C. Leung.Man portable power needs of the 21 st century: I. Applications for the dismounted soldier. II. Enhanced capabilities through the use of hybrid power sources, J. Power Sources 91 (2000) 27-36.

[12] M.T.Penella, and M.G. Forner, Runtime extension of low-power wireless sensor nodes using hybrid-storage units IEEE Transactions on Instrumentation and Measurement 59 (2010) 857-865.

[13] S.R. Cain, A. Anderson, E. Tasillo, W. Infantolino, and P. Wolfgramm.Empirical evaluation of the improvement of battery output when coupled with a capacitor bank, J. Power Sources 268 (2014) 640644.

[14] C. G. Hochgraf, J. K. Basco, T.P. Bohn, and I. Bloom, Effect of ultracapacitor-modified PHEV protocol on performance degradation in lithium-ion cells, J. Power Sources 246 (2014) 965-969.

[15] R. Chandrasekaran, G. Sikha, and B.N. Popov,Capacity fade analysis of a battery/super capacitor hybrid and a battery under pulse loads-full cell studiesJ. Appl. Electrochem.35 (2005) 1005-1013. [16] R.A. Dougal, S. Liu, and R.E. White, Power and life extension of battery-ultracapacitor hybrids, IEEE Transactions on components and packaging technologies 25 (2002) 120-131.

[17] D. Shin, M. Poncino, and E. Macii,Thermal management of batteries using a hybrid supercapacitor architecture,Proceedings of the Conference on Design, Automation \& Test in Europe, European Design and Automation Association, (2014) 331-336.

[18] J. Cao, and A. Emadi, A new battery/ultracapacitor hybrid energy storage system for electric, hybrid, and plug-in hybrid electric vehicles, IEEE Transactions on Power Electronics 27 (2012) 122-132.

[19] M. Michalczuk, L.M. Grzesiak, and B. Ufnalski, A lithium battery and ultracapacitor hybrid energy source for an urban electric vehicle, Electrotechnical Review 88 (2012) 58-162.

[20] B. Wang, B. Cao, X. Zhou,A novel multimode hybrid energy storage system and its energy management strategy for electric vehicles, J. Power Sources 281 (2015) 432-443.

[21]. P. Suntharalingam, Y. Yang, and W. Jiang, Hybrid electric vehicles, inA. Emadi, (Ed) Advanced Electric Drive Vehicles, CRC Press, Boca Raton, FL, 2014, pp. 411-438.

[22] C.E. Holland, J.W. Weidner, R.A. Dougal, R.E. White, Experimental characterization of hybrid power systems under pulse current loads, J. Power Sources 109 (2002) 32-37.

[23] G. Sikha, and B.N. Popov, Performance optimization of a battery-capacitor hybrid system, J. Power Sources 134 (2004) 130-138. 
[24] D. Cericola, P.W. Ruch, R. Kötz, and P. Novák,Simulation of a supercapacitor/Li-ion battery hybrid for pulsed applications, J. Power Sources 195 (2010) 2731-2736.

[25] W. Pell, B. Conway,Peculiarities and requirements of asymmetric capacitor devices based on combination of capacitor and battery-type electrodes, J. of Power Sources 136 (2004) 334-345.

[26] A. Sato, Lithium ion capacitors: An effective EDLC

replacement,http://www.yuden.co.jp/ut/product/tech/articles/data/taiyoyuden_lithiumioncapacitors_white paper

.pdf/(assessed 16.04.12).

[27] C. Marumo, Design and performance of laminated lithium-ion capacitors, Proceedings of Advanced Capacitor World Summit 2008, San Diego, California, July 14-16, 2008.

[28] P.H. Smith, Lithium-ion capacitors: Electrochemical performance and thermal behavior, J. Power Sources 243 (2013) 982-992.

[29] A. Suszko, Lithium carbon monofluoride: The next primary chemistry for soldier portable power sources,http://www.dtic.mil/cgi-bin/GetTRDoc?AD=ADA481761/2006 (assessed 16.04.12).

[30] D. Rhode, M. Root, $\mathrm{Li} / \mathrm{CF}_{\mathrm{x}}$ cell and material development for high rate applications, Proceedings of the $37^{\text {th }}$ Power Sources Conference, Cherry Hill, NJ, 17-20 June 1996,350-352

[31] E. Listerud, W. White, and D. Darch, Thermal management of hybrid- $\mathrm{CF}_{\mathrm{x}}$ cells and batteries for portable power, Proceedings from 45th Power Sources Conference, Orlando, FL, June 9-12, (2014) 7578.

[32] J. Read, E. Collins, B. Pickarski, S. Zhang, LiFformation and cathode swelling in the $\operatorname{Li} / \mathrm{CF}_{\mathrm{x}}$ ) battery, J. Electrochem. Soc., 158 (2011) A504-A510.

[33] R. Hagiwara, T. Nakajima, and N.Watanabe,Kinetic study of discharge reaction of lithium $\square$ graphite fluoride cell, J. Electrochem. Soc., 135 (1988) 2128-2132.

[34] N. Watanabe, T. Nakajima, and R. Hagiwara, Discharge reaction and overpotential of the graphite fluoride cathode in a nonaqueous lithium cell, J. Power Sources, 20 (1987) 87-92.

[35] T. Reddy, Lithium primary batteries, in: T.B. Reddy (Ed), Linden's Handbook of Batteries, fourth ed., McGraw Hill, New York, 2011, pp. 14.8.

[36] A. Dey,Lithium anode film and organic and inorganic electrolyte batteries, Thin Solid Films, 43 (1977) 131-171.

[37] D. Linden, B. McDonald, The lithiumsulfur dioxide primary battery -Its characteristics, performance and applications, J. Power Sources,5 (1980) 35-55. 
Table I. Comparison of Lithium Primary D-Cell Technologies

\begin{tabular}{|l|c|c|c|c|}
\hline & $\mathrm{Li} / \mathrm{SO}_{2}$ & $\mathrm{Li} / \mathrm{MnO}_{2}$ & $\mathrm{Li} / \mathrm{CF}_{\mathrm{x}}$ & $\mathrm{Li} / \mathrm{CF}_{\mathrm{x}} \mathrm{MnO}_{2}$ \\
\hline $\begin{array}{l}\text { Capacity at 2 A } \\
(\mathrm{Ah})\end{array}$ & 7.5 & 11 & 19 & 16 \\
\hline $\begin{array}{l}\text { Open Circuit } \\
\text { Voltage (V) }\end{array}$ & 3.0 & 3.3 & 3.0 & 3.3 \\
\hline $\begin{array}{l}\text { Nominal Voltage } \\
(\mathrm{V})\end{array}$ & 2.8 & 3.0 & 2.6 & 2.6 \\
\hline $\begin{array}{l}\text { Operating } \\
\text { Temperature }\left({ }^{\circ} \mathrm{C}\right)\end{array}$ & -60 to +70 & -40 to +72 & -20 to +90 & -40 to +85 \\
\hline Weight (g) & 85 & 115 & 69 & 81 \\
\hline $\begin{array}{l}\text { Specific Energy } \\
(\text { Wh/Kg) @ } 12 \mathrm{~V}\end{array}$ & 255 & 287 & 716 (Al case) & 514 (Al case) \\
\hline $\begin{array}{l}\text { Manufacturer, } \\
\text { Number }\end{array}$ & $\begin{array}{c}\mathrm{SAFT}, \\
\mathrm{LO} 26 \mathrm{SX} *\end{array}$ & $\begin{array}{c}\mathrm{Ultralife}, \\
\mathrm{U} 10013^{* *}\end{array}$ & $\begin{array}{c}\text { Spectrum } \\
\text { Brands, BR-20 }\end{array}$ & $\begin{array}{c}\text { Eagle Picher, } \\
\text { LCF-133 }\end{array}$ \\
\hline
\end{tabular}

* Saft specifications document31033-2-1005 (October 2005). ** Ultralife specifications document UBI5099, Rev F20 (October 2010). ${ }^{+}$Rayovac marketing data sheet 123-BA02A (March 2016). ${ }^{++}$Eagle Picher preliminary technical data sheet for $\mathrm{Li}-\mathrm{CF}_{\mathrm{x}} / \mathrm{MnO}_{2}$ hybrid. 
Table II. Performance of D-Cells Discharged at Various Constant Currentsto a 2.0V Cutoff

\begin{tabular}{|c|c|c|c|c|c|}
\hline & \multicolumn{2}{|c|}{$\mathrm{Li} / \mathrm{SO}_{2}$} & \multicolumn{3}{c|}{$\mathrm{Li} / \mathrm{CF}_{\mathrm{x}} \mathrm{MnO}_{2}$} \\
\hline Current & Capacity & Highest Temp. & \multicolumn{2}{c|}{ Capacity } & Highest Temp. \\
\hline$(\mathrm{A})$ & $(\mathrm{Ah})$ & $\left({ }^{\circ} \mathrm{C}\right)$ & $\begin{array}{c}\text { to } 87^{\circ} \mathrm{C} \\
(\mathrm{Ah})\end{array}$ & $\begin{array}{c}\text { to } 70^{\circ} \mathrm{C} \\
(\mathrm{Ah})\end{array}$ & $\left({ }^{\circ} \mathrm{C}\right)$ \\
\hline 1 & 7.5 & 37 & 15.0 & 15.0 & 49 \\
\hline 2 & 7.1 & 45 & 15.2 & 15.2 & 69 \\
\hline 2.5 & 7.1 & 47 & 15.2 & 7.0 & 81 \\
\hline 3 & 7.0 & 52 & 10.1 & 7.1 & 87 \\
\hline
\end{tabular}


Table III. Results of Hybrid Testing

\begin{tabular}{|c|c|c|c|c|c|c|}
\hline \multirow{2}{*}{ Energy Storage Device } & \multirow{2}{*}{$\begin{array}{c}\text { Cycles } \\
1 \text { min@ @ 100W, } \\
9 \min @ 12 \mathrm{~W}\end{array}$} & \multicolumn{2}{|c|}{ Disposable Unit } & \multicolumn{2}{|c|}{ Reusable Unit } & \multirow{2}{*}{$\begin{array}{c}\text { Total } \\
\text { Weight/Volume } \\
\left(\mathrm{g} / \mathrm{cm}^{3}\right)\end{array}$} \\
\hline & & $\begin{array}{l}\text { Weight } \\
\text { (g) }\end{array}$ & $\begin{array}{l}\text { Volume } \\
\left(\mathrm{cm}^{3}\right)\end{array}$ & $\begin{array}{l}\text { Weight } \\
\text { (g) }\end{array}$ & $\begin{array}{l}\text { Volume } \\
(\mathrm{cm} 3)\end{array}$ & \\
\hline $1 \mathrm{Li} / \mathrm{SO}_{2} \mathrm{BA} 5590(5 \mathrm{~s} 2 \mathrm{p})$ & 0 & 1006 & 883 & 0 & 0 & $1006 / 883$ \\
\hline $1 \mathrm{Li} / \mathrm{CF}_{\mathrm{x}} \mathrm{MnO}_{2} \mathrm{BA} 5790(5 \mathrm{~s} 2 \mathrm{p})$ & 0 & 1030 & 883 & 0 & 0 & $1030 / 883$ \\
\hline $1 \frac{1}{2} \mathrm{Li} / \mathrm{CF}_{\mathrm{x}} \mathrm{MnO}_{2} \mathrm{BA} 5790(5 \mathrm{~s} 3 \mathrm{p})$ & 158 & 1561 & 1325 & 0 & 0 & $1561 / 1325$ \\
\hline $2 \mathrm{Li} / \mathrm{SO}_{2} \mathrm{BA} 5590(5 \mathrm{~s} 4 \mathrm{p})$ & 100 & 2012 & 1766 & 0 & 0 & $2012 / 1766$ \\
\hline $2 \mathrm{Li} / \mathrm{CF}_{\mathrm{x}} \mathrm{MnO}_{2} \mathrm{BA} 790(5 \mathrm{~s} 4 \mathrm{p})$ & 208 & 2060 & 1766 & 0 & 0 & $2060 / 1766$ \\
\hline $1 \mathrm{Li} / \mathrm{SO}_{2} \mathrm{BA} 5590(5 \mathrm{~s} 2 \mathrm{p})+\mathrm{LIC}$ & 47 & 1006 & 883 & 380 & 523 & $1386 / 1406$ \\
\hline $1 / 2 \mathrm{Li} / \mathrm{CF}_{\mathrm{X}} \mathrm{MnO}_{2} \mathrm{BA} 5790(5 \mathrm{~s} 1 \mathrm{p})+\mathrm{LIC}$ & 58 & 531 & 442 & 380 & 523 & $911 / 965$ \\
\hline $1 \mathrm{Li} / \mathrm{CF}_{\mathrm{x}} \mathrm{MnO}_{2} \mathrm{BA} 5790(5 \mathrm{~s} 2 \mathrm{p})+\mathrm{LIC}$ & 96 & 1030 & 883 & 380 & 523 & $1410 / 1406$ \\
\hline $1 \frac{1}{2} \mathrm{Li} / \mathrm{CF}_{\mathrm{x}} \mathrm{MnO}_{2} \mathrm{BA} 5790(5 \mathrm{~s} 3 \mathrm{p})+\mathrm{LIC}$ & 155 & 1561 & 1325 & 380 & 523 & $1941 / 1728$ \\
\hline
\end{tabular}


Table IV. Weight and Volume Comparison of Battery/Hybrid Systems (Power Source Cavity: $6.2 \mathrm{~cm} \mathrm{x} \sim 25.4 \mathrm{~cm} \mathrm{x} \sim 11.2 \mathrm{~cm}$ )

\begin{tabular}{|c|c|c|c|c|c|c|}
\hline & \multicolumn{2}{|c|}{8 Hour Duration } & \multicolumn{2}{|c|}{16 Hour Duration } & \multicolumn{2}{|c|}{24 Hour Duration } \\
\hline Power Source & $\begin{array}{c}\text { Total } \\
\text { Weight } \\
\text { (g) }\end{array}$ & $\begin{array}{c}\text { Total } \\
\text { Volume } \\
\left(\mathrm{cm}^{3}\right)\end{array}$ & $\begin{array}{c}\text { Total } \\
\text { Weight } \\
\text { (g) }\end{array}$ & $\begin{array}{c}\text { Total } \\
\text { Volume } \\
\left(\mathrm{cm}^{3}\right)\end{array}$ & $\begin{array}{c}\text { Total } \\
\text { Weight } \\
\text { (g) }\end{array}$ & $\begin{array}{c}\text { Total } \\
\text { Volume } \\
\left(\mathrm{cm}^{3}\right)\end{array}$ \\
\hline $\mathrm{LIC}+1 / 2 \mathrm{BA}-5790,5 \mathrm{~s} 1 \mathrm{p}$ & 911 & 965 & - & - & - & - \\
\hline LIC + 1 BA-5790, 5s $2 p$ & 1410 & 1406 & 1410 & 1406 & - & - \\
\hline $\mathrm{LIC}+1 \frac{1}{2} \mathrm{BA}-5790,5 \mathrm{~s} 3 \mathrm{p}$ & $1872 *$ & $1766^{*}$ & $1872 *$ & $1766^{*}$ & $1872 *$ & $1766^{*}$ \\
\hline LIC + 1 BA-5590, 5s $2 p$ & 1386 & 1406 & - & - & - & - \\
\hline $1 \mathrm{BA}-5590,5 \mathrm{~s} 2 \mathrm{p}$ & - & - & - & - & - & - \\
\hline $2 \mathrm{BA}-5590,5 \mathrm{~s} 4 \mathrm{p}$ & 2012 & 1766 & 2012 & 1766 & - & - \\
\hline $1 \mathrm{BA}-5790,5 \mathrm{~s} 2 \mathrm{p}$ & - & - & - & - & - & - \\
\hline 2 BA-5790, 5s $4 p$ & 2060 & 1766 & 2060 & 1766 & 2060 & 1766 \\
\hline $11 / 2$ BA- $5790,5 \mathrm{~s} 3 p$ & 1561 & 1325 & 1561 & 1325 & 1561 & 1325 \\
\hline
\end{tabular}

* Uses Design 1 (Single-Unit). 